ZOOLOGIA 31 (6): 557-560, December, 2014

http://dx.doi.org/10.1590/S1984-46702014000600004

\title{
A new species of Oeda (Hemiptera: Membracidae: Stegaspidinae) from Madre de Dios, Peru
}

\author{
Albino M. Sakakibara \\ Departamento de Zoologia, Universidade Federal do Paraná. Caixa Postal 19020, 81531-980 Curitiba, PR, Brazil. \\ E-mail: amsakakibara@pq.cnpq.br
}

\begin{abstract}
A new species of Oeda Amyot \& Serville, 1843 - Oeda (Oeda) mielkei sp. nov. from Peru, Madre de Dios, $12^{\circ} 52^{\prime} \mathrm{S}, 71^{\circ} 22^{\prime} \mathrm{W}$ - is described. It differs from the other species of $\mathrm{O}$. (Oeda) in having the inflated pronotal process more elongate, and amber color; the suprahumeral horns are much more developed, club-shaped, about as long as the width of head, forming an arch with the tips touching each other; the metopidium, in lateral view, is almost vertical above head. A key, including images of all species (except O. mirandai Fonseca) are also provided.
\end{abstract}

KEY WORDS. Auchenorryncha; description; Stegaspidini; taxonomy treehopper.

Oeda Amyot \& Serville, 1843 is one of the most distinctive and remarkable of all treehopper genera. Species of the genus are easily recognizable by their enormously inflated, translucent and reticulate-textured pronotum. They are distributed throughout the lowland tropical rainforest areas of South America and in Central America as far north as Costa Rica. The function of the bizarre pronotal modifications in the genus are unknown but previous authors have speculated that they mimic plant parts or that the inflated pronotal process breaks off as a defense mechanism against predators (CRYAN \& DeITZ 1999).

Fabricius (1787) described a species, from Cayenne, French Guyana, which he characterized as "Thoracis folio inflato testaceo reticulato" and named it as Membracis inflata.

Amyot \& Serville (1843) created Oeda to include Fabricius' species Membracis inflata. WESTWOOD (1842) described Smilia informis from Brazil. FAIRMAIRE (1846) reorganized the so called "Tribu des Membracides" and, in regard to Oeda, he not only redescribed the genus together with $O$. inflata (Fabricius), but also included two other species: Oeda inermis, a new one from Brazil, characterized as "thorace antice inermis" (with an indication that it was equal to O. inflata in the sense of Perty), and $O$. informis (Westwood) whose description the author sent to Fairmaire - "Albida, pronoto maximo valde inflato, totum corpus obtegente, in medio constricto, et ad apicem spina armato; dorso irregulariter areolato; areis, praesertim posticis, maximis, fusco interdum marginatis et maculatis; alis anticis venis crassis punctoque subapicali fuscis.". STÅL (1869), dealing with membracids described by Fabricius, discovered that $O$. inflata treated by Fairmaire (1846) was based on a different species than $O$. inflata of Fabricius. According to the description given by Fairmaire the pronotum bears two processes anteriorly - "thorace antice bihamato". Therefore, STÅL (1869) proposed a new name for this species - Oeda hamulata (replacement name for O. inflata Fairmaire, 1846 nec Fabricius, 1787). BuckTon (1903) proposed another species from Brazil, Oeda frondosa, which he stated to be similar to O. inermis Fairmaire in the aspect of the pronotal process without anterior horns. FunkHouser (1927) catalogued O. inermis Fairmaire and $O$. frondosa Buckton as synonyms of $O$. inflata (Fabricius). FonsECA (1951) revised the genus and added one more species, Oeda mirandai. He also considered two subgenera within Oeda, passing O. informis into the new subgenus - Oedacanthus. CRYAN \& DeITz (1999) revised Stegaspidini, providing an accurate redescription for each genus, adding also keys to subgenera and species. In regard to Oeda mirandai Fonseca, 1951, they stated: "The type specimen of $O$. mirandai was not examined. Based on the original description, the difference between this species and $O$. hamulata seems to lie solely in the relative lengths of their balloon-like posterior pronotal processes. Some specimens examined in this work have pronota like O. hamulata, except the suprahumeral horns are reduced to mere nubs. If these specimens represent $O$. mirandai, then there is no doubt about that species' validity." Unfortunately the type specimen of O. mirandai Fonseca was not found in the collection of Museu de Zoologia, Universidade de São Paulo, São Paulo, Brazil (MZSP) where should be deposited. According to Dr O. Evangelista, MZSP (pers. commun.) the type is probably lost.

Oeda Amyot \& Serville contains four species (CrYan \& DeITZ 1999, McKamey 1998): one in the subgenus Oedacanthus Fonseca, 1951, Oeda (Oedacanthus) informis (Westwood, 1842), and three in Oeda s. str. -, Oeda (Oeda) inflata (Fabricius, 1787), Oeda (Oeda) hamulata Stål, 1869, and Oeda (Oeda) mirandai Fonseca, 1951.

In this paper a new species is described: Oeda (Oeda) mielkei sp. nov. Photographs of the holotypes of Membracis inflata Fabricius, 1787 and Oeda hamulata Stål, 1869 are also included.

2014 Sociedade Brasileira de Zoologia | www.sbzoologia.org.br | www.scielo.br/zool All content of the journal, except where identified, is licensed under a Creative Commons attribution-type BY-NC. 


\section{Key to subgenera and species of adult Oeda (Modified from FonseCA 1951 and CRYAN \& DeITZ 1999)}

1. Swollen pronotal process sessile (Figs 1 and 7-9), yellowish or amber, with finely reticulate areas; posterior process unarmed apically; forewings with apical cell-5 larger than the discoidal cell. Subgenus Oeda Amyot \& Serville ....... 2

$1^{\prime}$. Swollen pronotal process pedunculate (Fig. 8), translucent, glassy, without finely reticulate areas; posterior process with spiny (thornlike) apical projection; forewings with apical cell-5 smaller than the discoidal cell. Subgenus Oedacanthus Fonseca
2. Anterior of pronotal swelling without two digitate suprahumeral horns (Fig. 7)Oeda (Oeda) inflata (Fabricius)

2 '. Anterior of pronotal swelling with two digitate suprahumeral horns (Figs 1-4, 9-10)

3. Posterior pronotal process extending beyond wing apices (at rest)

4

3 '. Posterior pronotal process not extending beyond wing apices Oeda (Oeda) mirandai Fonseca.

4. Suprahumeral horns shorter than width of head (Figs 9-10) Oeda (Oeda) hamulata Stål

$4^{\prime}$. Suprahumeral horns as long as width of head (Figs 1-4) ... .. Oeda (Oeda) mielkei sp. nov.
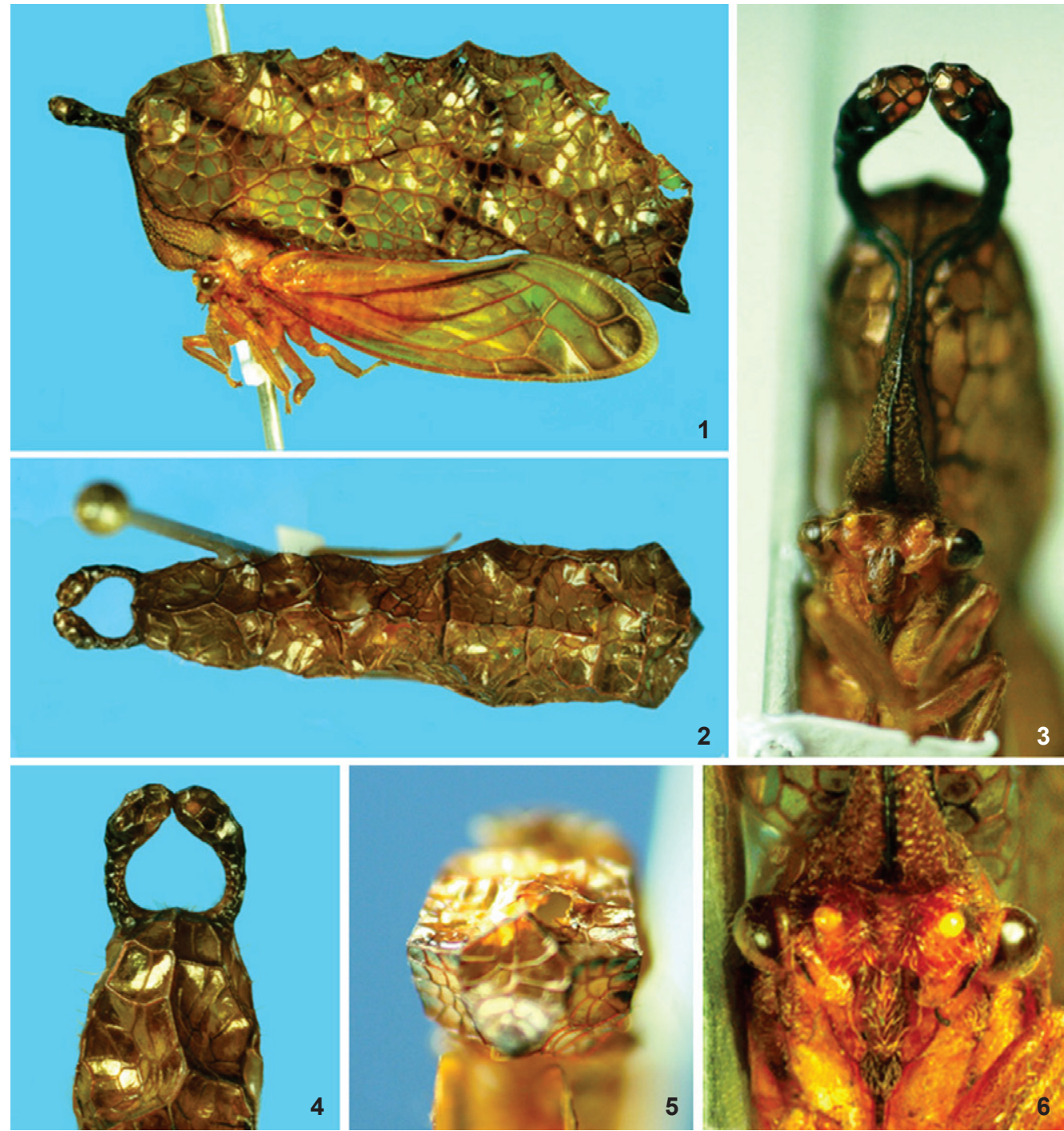

Figs 1-6. Oeda mielkei sp. nov., holotype female, DZUP: (1) habitus in lateral view; (2) habitus in dorsal view; (3) head and suprahumeral horns in anterior view; (4) details of suprahumeral horns in dorsal view; (5) apex of posterior process in posterior view); (6) head in anterior view. 

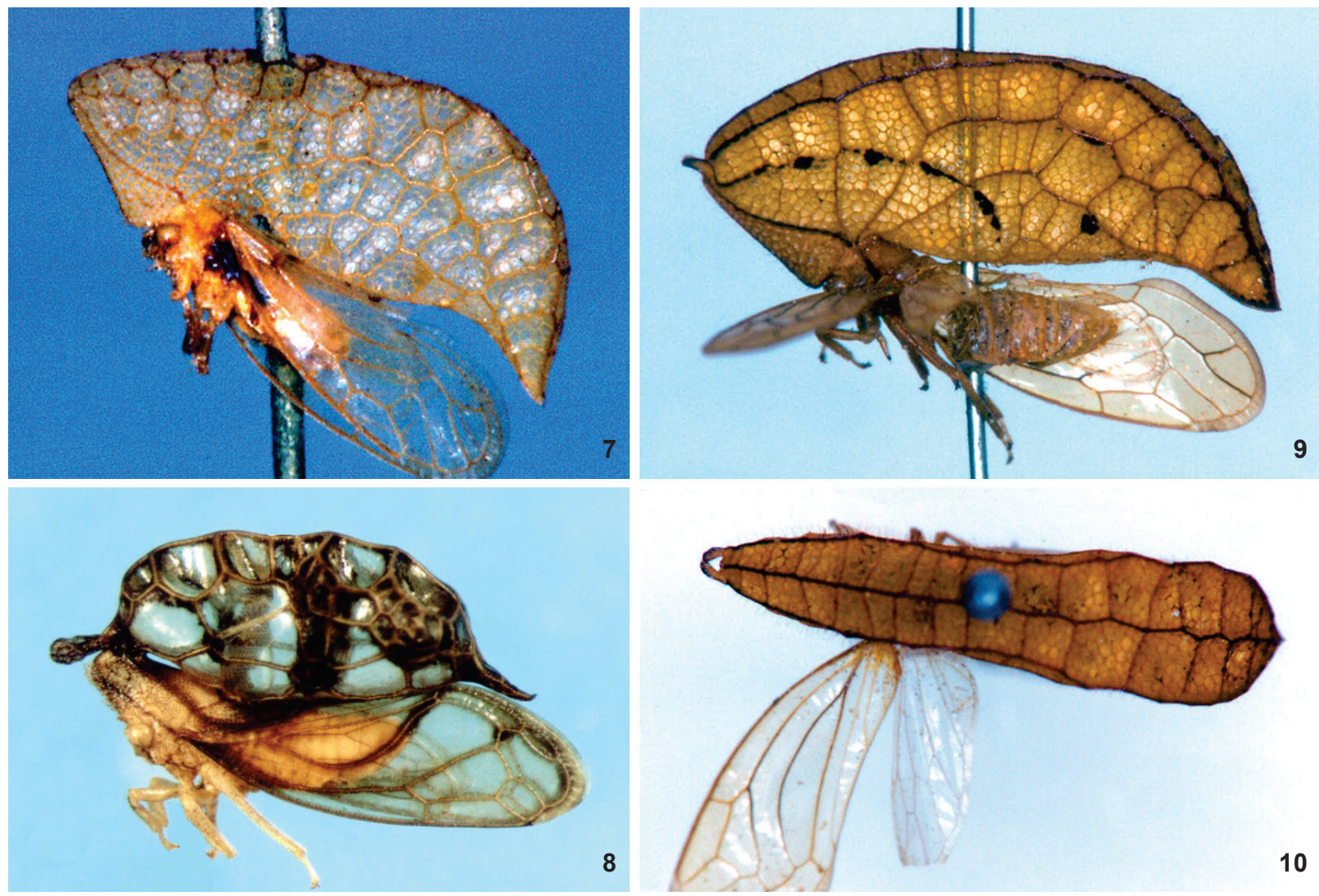

Figs 7-10. Habitus of three species of Oeda: (7) Membracis inflata, holotype female in lateral view; (8) Oeda (Oedacanthus) informis in lateral view; (9-10) Oeda hamulata, holotype female in lateral and dorsal views.

\section{TAXONOMY}

\section{Oeda (Oeda) mielkei sp. nov.}

\section{Figs 1-6}

Diagnosis. Pronotum elevated above head, inflate in balloon-like process, about four times longer than wide, in lateral view; posterior process slightly surpassing apex of forewings in repose; metopidium compressed and almost vertical above head; suprahumeral processes club-like, about as long as width of head, projected horizontally forward, converging distally in arch with tips touching.

Measurements (mm). Female. Total length 16.60; length of suprahumeral horn 2.20; width of head 2.32; length of forewing 9.80 .

Description. Holotype female. Pronotum yellowishbrown; supra-antennal lobes with margins black; suprahumeral processes dark-brown; reticulation veins dark-brown also some dots along main veins near middle and on posterior part; forewings yellow-amber, transparent, slightly infuscate at apex; thorax and abdomen reddish-yellow; legs pale.
Head (Figs 1 and 3) triangular, twice broader than long; eyes globular, almost pedunculate; vertex concave at middle; ocelli large, located on small elevation, much closer to eyes and superior margin of head than to each other; supra-antennal lobes foliaceous, with margins turned forward; frontoclypeus egg-shaped, twice longer than wide, extended its half beyond the supra-antennal lobes.

Pronotum (Figs 1 and 2) inflated above head in a balloonlike process, semitransparent, close to internal margins of forewings, entirely reticulate, about three times longer than wide, with superior and inferior outlines more or less parallel, in lateral view. In dorsal view, with median carina percurrent from base of metopidium to near apex of posterior process, laterally compressed, slightly dilated backwards and abruptly pointed. Metopidium narrow and compressed, almost vertical above head; surface micro-reticulate, provided with two thin black lines at each side converging in direction to base of suprahumeral processes. Suprahumeral processes elongate, almost as long as width of head, club-like, projected horizontally forward, curved inward, more or less in arch, with tips touching each other (Figs 1-4). Posterior process with main veins little evident in delimi- 
tating large areas of reticulation, but visibly elevated in regard to concave cells (Fig. 1); in dorsal view, slightly constricted at middle, and apical third gradually descending to an angulated apex attaining little beyond apex of forewings (Figs 2 and 5).

Forewings (Fig. 1) with five apical and one discoidal cell (crossveins $s$ and $m$-cu present); apical cell-5 larger than discoidal cell. Hindwings with four apical cells. Legs simple, prismatic; metathoracic tibiae with cucullate setae on row II-III.

Male. Unknown.

Material examined. Holotype female. Peru. Madre de Dios. "23-28-X-2013 AMAZONIA/LODGE. MADRE DE DIOS/(próx. ATALAYA. CUZCO)./PERU. $12^{\circ}$ 52'S. $71^{\circ} 22^{\prime} \mathrm{W} / 500 \mathrm{~m}$ [a.s.l.] O. MIELKE LEG". The holotype is deposited in the "Coleção de Entomologia Pe. J.S. Moure", Departamento de Zoologia, Universidade Federal do Paraná, Curitiba, Paraná, Brazil (DZUP). The specimen presents the inflated portion of pronotum slightly damaged on dorsum.

Etymology. The species is named after the entomologist Olaf H.H. Mielke, a well-known specialist in Lepidoptera.

Remarks. This species is little bigger than the others belonging to Oeda (Oeda); it differs from them in having the inflated pronotal process more elongate, and amber color. The suprahumeral horns are much more developed, club-shaped, about as long as the width of head, forming an arch with the tips touching each other. The metopidium, in lateral view, is almost vertical above head (Fig. 1). In the other species, however, it is obliquely projected forwards (Figs 7-9). The pronotal main veins are inconspicuous, not clearly delimiting areas with numbers of cells, as observed in O. inflata (Fabricius) and O. hamulata Stål. The posterior process slightly surpasses the apex of forewings.

\section{LITERATURE CITED}

Амyot, C.J.B. \& J.G.A-Serville. 1843. Histoire Naturelle des Insectes - Hémiptères. Paris, Librairie Encyclopédique de Roret, p. 533-553.

Buckton, G.B. 1903. A monograph of the Membracidae. London, L. Reeve \& Company, p. 181-296.

Cryan, J.R. \& L.L. Deitz. 1999. Review of the New World treehopper tribe Stegaspidini (Hemiptera: Membracidae: Stegaspidinae): II: Lycoderes Germar, Oeda Amyot \& Serville, and Stegaspis Germar. Proceedings of the Entomological Society of Washington 101 (4): 760-778.

FABRICIUS, J.C. 1787. Ryngota. Mantissa insectorum sistens species nuper detectas adiectis synonymis, observationibus, descriptionibus, emendationibus 2: 1-382.

Fairmaire, L. 1846. Revue de la tribu des Membracides. Annales de la Société Entomologique de France 4: 235-320, 479-531.

FonsECA, J.P. DA. 1951. Contribuição para o conhecimento dos membracídeos neotrópicos. Arquivos do Museu Nacional 42: 211-219.

FunkHouser, W.D. 1927. Membracidae. General Catalogue of the Hemiptera. Fasc. 1. Northampton, Smith College, 581p.

McKamey, S.H. 1998. Taxonomic catalogue of the Membracoidea (exclusive of leafhoppers): second supplement to fascicle I Membracidae of the General Catalogue of the Hemiptera. Memoirs of the American Entomological Institute 60: 1-377. STÅL, C. 1869. Hemiptera Fabriciana. Öfversigt af Kongl. Vetenskaps-Akademiens Förhandlingar 8: 1-130.

WESTWOOD, J.O. 1842. Insectorum novorum centuria, auctore. Annals and Magazine of Natural History 9: 118-119.

Submitted: 23.IX.2014; Accepted: 13.X.2014.

Editorial responsibility: Ângelo Parise Pinto

ZOOLOGIA 31 (6): 557-560, December, 2014 